ISSN: 2716-1277

e-ISSN: 2716-1269

Available online at

TLIC https://jlic.iain-jember.ac.id/
Journal of Language Intelligence and Culture

Fakultas Tarbiyah dan Ilmu Keguruan

IAIN Jember

Vol 2, No.1, Page 91-100, June 2020

\title{
English Speaking Skill and Language Component Practice: englisch-hilfen.de in Assistance
}

\author{
Nurul Huda, \\ IAIN Jember \\ my.sinau@gmail.com
}

Husnul Hotimah, husnulhotimah4@gmail.com

\section{ARTICLE INFO \\ Article History: \\ Accepted: March 2020. \\ Approved: May 2020. \\ Published: June 2020 \\ Key Words: \\ Speaking Skill, Vocabulary, \\ CALL}

DOI: $10.35719 / j l i c . v 2 i 1.19$

\begin{abstract}
The students, most of the time, face difficulties in learning English, especially in mastering speaking skill. One of the most common problems faced in the teaching and learning process for speaking skill is the lack of motivation and students tend to use their first language. As the developing of technology, the teacher is required to involve digital teaching, especially related to the use of computer. Employing computer or Computer-Assisted Language Learning (CALL) in the teaching and learning process is highly recommended for a fun and exciting learning. In this particular case, englishch-hilfen.de serves as answer for those seeking such learning process. A qualitative study was involved to identify how the use of englishch-hilfen.de can improve and give significant effect for students' English performance, especially for speaking and vocabulary aspect. The result of this study suggested that the content within englishch-hilfen.de is very beneficial for it provides such meaningful and stimulating activities for English language students.
\end{abstract}

\section{INTRODUCTION}

Speaking is the process of building and sharing meaning through the use of verbal and non-verbal symbols, in a variety of contexts (Chaney, 1998). Yet, Huebner (1960) argued that speaking 


\section{JLIC}

is a skill used by someone in daily life communication whether at school or outside. He added, language is essentially speech, and speech is basically communication by sounds. The skill is acquired by much repetition; it primarily a neuromuscular and not an intellectual process. It consists of competence in sending and receiving messages. From those explanations, we can conclude that speaking is an activity that used expressions to deliver ideas, opinions and feelings to others by using words and sounds of articulation in order to inform, to persuade or to entertain someone.

Richard (2008) proposes three functions of speaking, in which these functions are the expanded version of the Brown and Yule's framework, they are: (1) talk as interaction, which cover the aspect of interacting with others in conversation of daily life, (2) talk as transaction, which cover the aspect of getting certain information through conversation, and (3) talk as performance, which cover the aspect of how to give or present our opinions, thoughts, or ideas in public or in front of other people.

One of the ways to overcome the problem in the aspect of speaking skill complexity is by using Computer-Assisted Language Learning. According to Levy (1997), Computer-Assisted Language Learning (CALL) is the search for and study of applications of the computer in language teaching and learning. The main aim of CALL is to find ways for using computers for the purpose of teaching and learning the language. More specifically, CALL is the use of computer technologies that promote educational learning, including word processing, presentation packages, guided drill and practice, tutor, simulation, problem solving, games, multimedia CD-ROM, and internet applications such as e-mail, chat and the World Wide Web (WWW) for language learning purposes. Here the use of Englisch-hilfen.de is as Computer as Tutor. As I have explained before that this website is a complete package to learn English. It shows you brief explanation about material like grammar and vocabulary, because this website is focus on them and it also complete with the exercises and the students don't need to get 
worried about their answer whether their answer is right or wrong because this website provide checker and the right answer so the students the can learnt by themselves.

The use of the website brings some advantages such as below.

a. It is very useful to teach grammar and vocabulary

This site is more focus on Grammar and Vocabulary. We can find complete knowledge about grammar and vocabulary for the beginner until advance level.

b. It loads faster

This website does not take much memory $(\mathrm{kb})$ to proceed. Maybe the reason is this website does not content a lot of pictures or widgets.

c. Downloadable worksheets

This website also offers a menu to download worksheets such as Grammar tenses, some printable task and exercises and many others.

d. It provides so many lists of vocabularies in many topics

The lists of vocabularies are provided in tables, complete with the examples. We can find so many topics here. The pictures are also available in certain topic.

e. The theories are presented clearly in a table

The theories are presented in a brief yet clearly in the form of table that consist of explanations, formula, examples, word choices and many other features that we can find both in the theory of Vocabulary and Grammar.

Therefore, as it was explained, mastering English, especially speaking skill, can be said to be one of the most complex activity to be done. Not only it covers some micro skills in regards to the language component, but also the macro one related to the aspect of meaning and intention of the speaking itself. That is why, in this particular case, such a technique involving Computer-Assisted Language Learning in the form media is urgently needed. One of the media that can be used is englishch-hilden.fe to help and assist the students to have better understanding in English subject. 


\section{JLIC}

\section{METHODS}

The purpose of this study is to give better and comprehensible insight about using the platform of englishchhilfen.de within the teaching and learning process. It applied qualitative research by using descriptive approach. Nassaji (2015) suggests that both qualitative and descriptive serves as approach dealing within naturalistic data. It means that the main focus is to describe what happens and what something is about. It more concern on the aspect of what rather than how and why something occurs and happens (Gall, Gall, \& Borg, 2007). The data were collected by using documentation focusing on the primary data, related to the platform used or englishch-hilfen.de itself, and the secondary data related to other sources in form of books, journal articles, or any relevant sources to the subject investigated. Moreover, the data was analyzed descriptively employing the inductive and deductive approach.

\section{RESULTS AND DISCUSSION}

\section{The Platform of englishch-hilfen.de}

The http address for the site is "http://www.englischhilfen.de/en/'. This Learning English Online website consists of English Grammar, Vocabulary, Exercises, Exams, and information for learners of English as a foreign language. The owner of this site is Joerg Poehland from Germany.

There is some list of options in the left column of the page on the homepage websites. This menu consists of a list of links to help us find the content of the website. Here are some important links that is very useful to learn English from the content in this website.

1. Grammar Explanations

This menu consists of some theories about English grammar. Every link will lead us to a simple explanation about various 
explanations of grammar. It also provides examples and table of formula with clear explanation. This list of links will appear if we click the Grammar Explanations menu. By clicking one of these links, we can get the theory and examples of the grammatical features.

\section{Grammar Exercises}

This menu consists of some exercises from the Grammar Explanation. There are so many grammar exercises from this menu. The online exercises could be in a form of short answer, multiple choice, correcting the wrong grammar, rearrange jumbled words, etc. If we had done the test, we can check what score that we got and the wrong and correct answer of the test.

\section{Vocabulary Explanations}

This menu consists of brief explanations and some examples of vocabulary in certain topic. We may choose one of the vocabulary knowledge that we want to know by clicking one of these links:

This menu consists of some exercises from the Vocabulary Explanation. If we had done the test, we can check what score do we get and the wrong and correct answer of the test. If we answered the questions wrong, there is an explanation of how to solve the problem in the 'comment' link under the correct answer. It consists of some tests, which questions are randomly selected on special topic.

4. Test

It consists of short tests that we can use to test English Grammar and vocabulary knowledge.

5. Exam

Here we will find test or examinations of English as a foreign language. It consists of two options: Grammar and words and Oral Exams

6. Daily English Lesson

In this menu, we can find some unspecified topic such us reading texts and listening comprehension together with its exercises. 


\section{JLIC}

\section{English Forum}

This website also has an English Forum to help the members discuss about the English language. Especially for English teachers who experience difficulties in their classroom, then they can share and discuss in this forum

8. Talks

It provides the information about how to talk in English. There are other options in this menu such as: Learning English Talks. Here you will find useful information for talks. Techniques, Talks, Customs and Traditions, and Quotations

\section{Download Worksheets}

We can also download worksheets such as Grammar tenses, some printable task and exercises and many others. The worksheets will help the teachers to provide tasks to the students.

10. Writing

Here, you will find some information about writing skill. The theories, examples and many others. The links that you could find from this writing section are:

11. Games

From this submenu, we could find so many kinds of games to learn English in a form of Hangman, Find the pairs and Quizzes, Find the words and other kind of game.

\section{Role-play as the Teaching Method}

Role-playing is defined as participation in simulated social situations that are intended to throw light upon the role/rule contexts governing real life social episodes (Cohen, Manion and Morrison, 2007). In defining role play, Byrne (1986) gave comments that role play is a part of drama activity. In details, he described that there are three terms to cover the drama activities. They are mime (mimicry-memorization), role play and simulation. Further, he distinguished the terms as follows:

1. Mime, the participants perform actions without using words (although as we shall see, this activity leads naturally on to talk). 
2. Role play, the participant interact either as themselves in imaginary situations.

3. Simulation, this involves role play as defined above. However, for this activity the participants normally discuss a problem of some kind with some setting that has been defined for them. Both role play and simulation are commonly used in foreign language classes to facilitate communicative competence. Whereas mime seems more appropriate as a language game. It is performing actions without using words. For instance, if someone mimes and action, the others try to guess what it is.

He also mentioned some beneficial of using role play such as follows.

1. It's fun and motivating

Students will be more motivated and eager to participate if we present them with a realistic situation that might encounter in daily lives. Using realistic situations gets students to practice essential vocabulary and phrases in such a way they will be better able to retain what they learn.

2. It's all in the details

Role play are opportunity for students to produce natural, semi-spontaneous speech. When setting up a role play, we should give enough information about the situation to evoke the vocabulary you are targeting, but it should leave enough to the imagination to allow the students to construct their speech on the spot.

3. Build self-confidence

Why students are reluctant to speak? When they are standing in front of their friends alone. They will get nervous, confuse what they have to say, get worried about the diction, pronunciation and etc. But if they have partner so they will get their quiet and they will express themselves like what they want.

4. Develop listening skill 


\section{JLIC}

Good role-playing requires good listening skills. In addition to understanding the words the other person is saying, it's important to pay attention to body language and non-verbal clues. Better to have your team develop these skills while role-playing than when they're trying to perform in the real world.

5. Improving communication between one students to the others and solve a problem

When we give them a chance to make a note when they are planning, of course it will force them to communicate each other or to be cooperative. Solve problem means if the teacher gives them a topic what they have to act in front of the class, what situation will raise in the dialogue and what they have to say so they must discuss it with their pair or group.

\section{Implementing 'englishch-hilfen.de' in the Teaching of Speaking}

To improve the eighth grade students' speaking skill and vocabulary using this website, the technique applied is asking the way. The steps are such as follows.

1. Exploration stage; Asking them some simple questions about directions. For example: where is the nearest post office. Where is the nearest hospital?

2. Elaboration stage

a. Presenting the material we are going to use. Ask them to look at the projector

b. Introducing the Englisch-hilfen.de website, and ask them to visit it when they want to study English at home.

c. Going to the topic that is already provided by the website. Because we want to teach the students vocabularies about Asking The Way first, we should find the material by clicking this following steps: >> Home >> Vocabulary explanation >> Vocabulary Lists >> 
Asking the way. Show the students every expression and pictures in the website.

d. Explaining about how to use that expression. Ask them to understand and remember the expressions from the picture given. Give them some minutes to understand the topic if it is needed.

e. Asking them to repeat after the expression in the web.

f. Giving them another expression that we also can find in the website by clicking Home $>>$ Vocabulary explanation >> Vocabulary Lists >> Asking the way - phrases. At this step, we will be more focus on the speaking skill.

g. Asking them to repeat after the expression in the web.

h. Giving the students some examples of dialogue about asking and giving directions from the web.

i. Analyzing which expression from the Vocabulary List that the students feel it difficult to learn. We need to repeat and drill the students to make them familiar with the expression.

j. Asking the students to make pairs. If they are ready with their pairs, ask them to pay attention about the instruction about what will they do for their task.

k. Showing the students Google map. Explain a little bit about it. Explain to the students about what they are going to do with Google map.

1. Asking them to work without any noise.

3. Confirmation Stage

a. Asking them to present their work in front the class if they are ready.

b. Correcting the wrong utterances and expressions.

c. Asking them what they got from today's lesson.

d. Concluding the lesson.

\section{CONCLUSION}

The implementation of englishch-hilfen.de, alongside applying the teaching method of role-play, may help the students to 


\section{JLIC}

improve their speaking skill and vocabulary. The students can act like somebody else, they have a partner so they can speak and feel confidence in front of their friends, they don't need to worried about the expression they have to use because they have learnt from the website and they could see the picture so it will help the students to memorize the vocabularies and google map show the direction so it will help the students in constructing the dialogue.

\section{REFERENCES}

Brown, H. D. (2004). Language Assessment: Principles and Classroom Practices. New York: Longman.

Byrne, Donn, 1986. Teaching Oral English: Longman Handbooks for English Teacher.\Singapore: Longman Group.

Chaney, A. L and F L. Burk. 1998.Teaching Oral Communication. in Grades K:2005. Boston: Allyn \& Bacon.

Cohen, L., Manion, L., \& Morrison, K. 2007. Research Methods in Education (6th ed.). London, New York: Routllege Falmer.

Gall, M.D., Gall, J.P., \& Borg, W.R. (2007), Educational research: An introduction (8th ed.). Boston: Pearson.

Huebner, Theodore. 1960. Audio Visual Technique in Foreign Language. New York: Cambridge University Press.

Levy, M. (1997) CALL: Context and conceptualization. Oxford: Oxford University Press.

Nassaji, H. (2015). Qualitative and descriptive research: Data type versus data analysis. Language Teaching Research. 19 (2): 129-132.

Richards, J. C. (2008). Teaching Listening and Speaking. Cambridge: Cambridge University Press. 